\title{
Molecular study on Senecio fontanicola (S. doria group, Asteraceae) and its conservation status
}

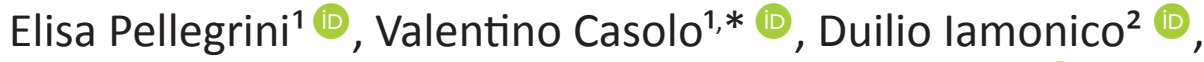 \\ Giuseppe Oriolo ${ }^{3}$, Nicola Rovere ${ }^{4} \&$ Massimo Vischi ${ }^{1}$ (i)
}

Key words: alkaline fens, DNA barcoding, conservation status, Senecioneae.

Ključne besede: bazična nizka barja, sistem črtnih kod DNK, ohranitveni status, Senecioneae.

Received: 8. 6. 2018

Revision received: 31. 8. 2018

Accepted: 3. 9. 2018

\begin{abstract}
Senecio fontanicola is endemic to black-bog-rush fens of southern Austria, northwestern Slovenia and north-eastern Italy. It is characterized by oblanceolate leaves, a low number of supplementary bracts and glabrous achenes and it grows in marshy spring areas, fens and reed beds, between elevations from 20 to $850 \mathrm{~m}$. The species was never described with molecular traits and during the last decades, $S$. fontanicola showed a dramatic decline due to land reclamation for agriculture. Therefore, the present study aims to characterize $S$. fontanicola using the molecular barcoding technique and to updated its distribution to propose a global risk category for the species, based on IUCN criteria. The three molecular

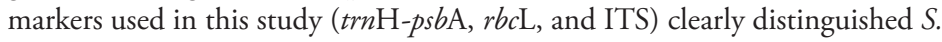

fontanicola from $S$. doria. s.s. and the revised distribution allowed the definition of the conservation status of the species, that is Endangered-EN B2ab(i, ii, iii, iv) following the $\mathrm{B}$ criterion of the IUCN guidelines.
\end{abstract}

\section{Izvleček}

Senecio fontanicola je endemit barij s črnikastim sitovcem v južni Avstriji, severozahodni Sloveniji in severovzhodni Italiji. Ima značilne ozko narobejajčaste liste, majhno število dodatnih krovnih listov in golih rožk. Uspeva v močvirnatih povirjih, barjih in trstiščih na nadmorskih višinah med 20 in $850 \mathrm{~m}$. Vrste do sedaj še niso opisali z znaki, pridobljenimi z molekularnimi analizami. V zadnjih desetletjih je $S$. fontanicola doživela dramatičen upad rastišč zaradi melioracij v kmetijska zemljišča. V naši raziskavi smo želeli opisati $S$. fontanicola z molekularno tehniko črtnih kod DNK in prikazati najnovejšo razširjenost vrste. Predlagali smo tudi globalno kategorijo ogroženosti po IUCN kriterijih. Uporabili smo tri molekulske markerje ( $t r n \mathrm{H}-p s b \mathrm{~A}, r b c \mathrm{~L}$, and ITS), $s$ katerimi smo jasno ločili vrsto S. fontanicola od S. doria. s.s. S kritično presojo pojavljanja vrste smo opredelili ohranitveni status kot Ogrožena vrsta-EN B2ab(i,ii,iii,iv) v skladu z B kriterijem po navodilih IUCN.

\footnotetext{
1 Department of Agriculture, Food, Environmental and Animal Science, University of Udine, via delle Scienze 206, 33100 Udine, Italy.

2 Laboratory of Phytogeography and Applied Geobotany, Department of Planning, Design, and Technology of Architecture, University "La Sapienza", Via Flaminia 72, 00196 Rome, Italy.

3 Via T. Ciconi 26, 33100 Udine, Italy.

4 Via Mazzini, 14 - 33100 Udine, Italy.

* Corresponding author. Plant Biology Unit, Department Agriculture and Environmental Science, University of Udine, via delle Scienze 91 , 33100 Udine, Italy. E-mail: valentino.casolo@uniud.it Tel. (+39) 0432558797; Fax. (+39) 0432558784
} 


\section{Introduction}

Senecio L. (Compositae, Senecioneae) is a genus of approximately 1250 species (Nordenstam 2007) with cosmopolitan distribution and the primary centre of diversity in South Africa and South America (Pelser et al. 2007, Milton 2009). Molecular and phylogenetic investigations clearly showed that this genus is highly complex, listing several critic groups (see e.g. Pelser et al. 2010, Iamonico 2017).

According to Calvo \& Aedo (2015) the $S$. doria group is represented in Europe by the following species: $S$. altissimus Mill. (Spain, France, Italy, and Morocco), $S$. bithynicus J. Calvo (Turkey), S. doria L. (Austria, Bulgaria, Czech Republic, Hungary, Kazakhstan, Moldova, Russia, Romania, Serbia, Slovakia, and Ukraine; see also Iamonico 2013, Calvo et al. 2014) S. fontanicola Grulich \& Hodálová (northern Italy, north-western Slovenia and Austria), S. legionensis Lange (endemic to north-western of the Iberian Peninsula), S. morisii J. Calvo \& Bacch. (Sardinia), and S. umbrosus Waldst. \& Kit. (Central-Eastern Europe and Ukraine).

Senecio fontanicola is an endemic species distributed along north-eastern Italy, Carinthia (Austria) and northwestern Slovenia, whose taxonomic position was proposed by Grulich \& Hodálová (1994) on the basis of morphological data. Ecologically, S. fontanicola is strictly linked to black-bog-rush fens between elevations of 20-850 $\mathrm{m}$, recorded in: i) Primulo farinosae-Schoenetum ferruginei Oberd. (1957) 1962 in Carinthia, Austria (Grulich \& Hodálová 1994); ii) Erucastro-Schoenetum nigricantis Poldini 1973 emend. Sburlino e Ghirelli 1994, in Friuli Venezia Giulia, Italy (Poldini \& Oriolo 2002); iii) Carici paniculatae-Salicetum myrsinifoliae Dakskobler 2012, in the Zelenci area in Slovenia (Vreš et al. 2012).

The occurrence of $S$. fontanicola in Italy (erroneously identified as $S$. doria) date back to 1855 when Pirona (1855) highlighted the morphological variability of a population occurring in Virco fens (Friuli Venezia Giulia, north-east Italy), although there is no formal publication of a name (the annotation "S. doria v. angustifolium" occurs in a label of a specimen preserved at FI). About one century later, Zenari (1947: 3-4) described two new varieties for the Friulan populations, i.e. $S$. doria var. subdecurrens and $S$. doria var. golae. For the $S$. doria var. subdecurrens, two subvarieties were described, i.e. the sv. Typicus and the sv. Intermedius, distinguished each other by leaf shape and insertion to the stem, while for the $S$. doria var. golae only the sv. Forojuliensis was recorded by Zenari (1947: 3-4) in Italy. These taxa are currently considered heterotypic synonyms of $S$. doria (Poldini et al. 2001) and were recently lectotypified (Calvo $\&$ Aedo 2015).
The recent revision of Calvo \& Aedo (2015) clarified nomenclature, diagnostic characters, and distribution of the species belonging to $S$. doria group, $S$. fontanicola included. Before this contribution, the distribution of $S$. fontanicola in Italy was rather uncertain because the checklist of the Italian vascular flora (Conti et al. 2005; Scoppola \& Spampinato 2005) also wrongly recorded $S$. doria. The lack of solid information entailed that the conservation status of $S$. fontanicola was inaccurate. While the Austrian Red List considered S. fontanicola as an endangered (EN) species from 1999 (Niklfeld \& SchrattEhrendorfer 1999), Pignatti et al. (2001), which resume risk categories of the Italian National Red Lists (Conti et al. 1992; 1997), reported only $S$. doria as vulnerable species (VU). Moreover, S. fontanicola still missed in the following updating of the Italian National Red List edited by Rossi et al. (2013).

The present work aimed to characterize $S$. fontanicola from a molecular point of view, using the barcoding technique and including species erroneously attributed to $S$. doria s.l. (in particular to $S$. doria) or recently retrieved (i.e. S. altissimus). The amplified loci were $t r n \mathrm{H}-p s b \mathrm{~A}, r b c \mathrm{~L}$ and ITS, which are included in the loci recommended in the Consortium for Barcode of Life (CBOL) Plant Working Group (CBOL Plant Working Group 2009). The loci selection took into account i) the high discrimination power of $t r n \mathrm{H}-p s b \mathrm{~A}$ (Kang et al. 2017); ii) the great amount of data available in Genbank (Hollingsworth et al. 2016) on both $r b c \mathrm{~L}$ and ITS sequences; and iii) the common use of $t r n \mathrm{H}-p s b \mathrm{~A}$ and ITS markers for the genus Senecio (Khan et al. 2013). Moreover, the distribution of $S$. fontanicola is updated, especially regarding the Italian populations, and a conservation status proposed using the IUCN criteria (IUCN 2012).

\section{Materials and methods}

\subsection{Plant material}

Field sampling was carried out in summer 2009. Three populations of $S$. fontanicola were sampled in Italy and other three in Austria, while $S$. doria samples were provided by prof. Hodálová (Institute of Botany, Bratislava, Slovak Republic) and referred to 2 populations coming from Hungary and 1 population from Slovakia (Table 1). A fresh leaf was collected from at least five individuals for each population. Leaf samples of $S$. fontanicola were frozen in liquid nitrogen within few hours after their collection and stored at $-80{ }^{\circ} \mathrm{C}$. Leaf specimens of $S$. doria were dried after sampling and stored in sealed plastic bags with silica gel. 
Table 1: Sampling localities, geographic coordinates, and GenBank accession numbers for the three loci sequenced.

Tabela 1: Lokacije vzorčenja, geografske koordinate in pristopne številke iz sekvenčne podatkovne baze (GenBank) za tri sekvencirane lokuse.

Locality
Senecio fontanicola

Virco, Bertiolo, Udine (Italy)

Udine (Italy)

Vinchiaruzzo, Cordenons, Pordenone

(Italy)

Techelweg, Klagenfurt (Austria)

Trabesing, Klagenfurt (Austria)

Senecio doria

Podunajská nížina Lowland, Ňárad

(Topol'ovec, Slovakia)

$47^{\circ} 50^{\prime} 08^{\prime \prime} \mathrm{N}$

$17^{\circ} 35^{\prime} 16^{\prime \prime} \mathrm{E}$

South of Komárom (Újpuszta, Hungary)

Slovak Karst, between Turňa nad village (Slovakia) and Tornanádaska (Hungary)

$47^{\circ} 40^{\prime} 18^{\prime \prime} \mathrm{N}$ $18^{\circ} 08^{\prime} 00^{\prime \prime} \mathrm{E}$

$48^{\circ} 35^{\prime} 22^{\prime \prime} \mathrm{N}$ $45^{\circ} 58^{\prime} 43^{\prime \prime} \mathrm{N}$

$12^{\circ} 43^{\prime} 42^{\prime \prime} \mathrm{E}$

Geographic coordinates (WGS84)

$45^{\circ} 55^{\prime} 43^{\prime \prime} \mathrm{N}$ $13^{\circ} 03^{\prime} 30^{\prime \prime} \mathrm{E}$

$45^{\circ} 52^{\prime} 57^{\prime \prime} \mathrm{N}$ $13^{\circ} 13^{\prime} 25^{\prime \prime} \mathrm{E}$

$46^{\circ} 35^{\prime} 43^{\prime \prime} \mathrm{N}$ $14^{\circ} 06^{\prime} 42^{\prime \prime} \mathrm{E}$

$46^{\circ} 33^{\prime} 05^{\prime \prime} \mathrm{N}$ $14^{\circ} 15^{\prime} 00^{\prime \prime} \mathrm{E}$

$46^{\circ} 34^{\prime} 24^{\prime \prime} \mathrm{N}$ $13^{\circ} 45^{\prime} 12^{\prime \prime} \mathrm{E}$
GenBank accession numbers trn $\mathrm{H}-p s b \mathrm{~A}$ $r b c L$ ITS

KU307474

KU319493

KU319494

KU319495

KU319496

KU319497

KU319498

KU319499

KU319500

KU319501

KU319502

KU319503

KU319504

KU319505

KU319506

KU319507

KU319508

KU319509

KU319510

KU319511

KU319512

KU319513

KU319514

KU319515

KU319516

KU319517

KU319518

KU319519

KU319520

KU319521

KU319522

KU319523

KU319524

KU319525

KU319526

KU319527

KU308440

KU308441

KU308437

KU308438

KU308439

KU307475

KU307476

KU307477

KU307478

KU307479

KU307480

KU307481

KU307482

KU307483

KU307484

KU307485

KU308442

KU308443

KU307486

KU308444

KU308445

KU307487

KU307488

KU307489

KU308446

KU308447

KU308448

KU308449

KU308450

KU308451

KU307490

KU307491

KU307492

KU307493

KU307494

KU307495

KU308452

KU308453

KU308454

KU308455

KU307496

KU307497

KU307498

KU307499

KU307500

KU307501

KU307502

KU307503

KU308456 KU307504

KU307505

KU307506

KU319474

KU319475

KU319476

KU319477

KU319478

KU319479

KU319480

KU308416

KU308417

KU308418

KU308419

KU308420

KU308421

KU319481

KU308422

KU319482

KU308423

KU319483

KU308424

KU308425

KU319484

KU308426

KU319485

KU308427

KU319486

KU308428

KU319487

KU308429

KU308430
KU307457

KU307458

KU307459

KU307460

KU307461

KU307462

KU307463

KU307464

KU307465

KU307466

KU307467

KU307468

KU307469 


\subsection{DNA extraction, amplification and sequencing}

DNA extraction was carried out using the CTAB method (Doyle \& Doyle 1997). Primer sequences and amplification conditions of $t r n \mathrm{H}-p s b \mathrm{~A}, r b c \mathrm{~L}$, and ITS were reported by Sang et al. (1997), Hollingsworth et al. (2009), and Stanford et al. (2000) respectively, with slight modifications (Table 2). Loci were amplified by polymerase chain reaction (PCR) on the thermocycler GeneAmp ${ }^{\circ}$ PCR System 9700 (Applied Biosystem). The quality of the DNA extracted was checked on $0,8 \%$ agarose gel. The amplification products were purified and sequenced in both directions with the automatic sequencer Applied Biosystem 3730.

\subsection{Data analysis}

Forward and reverse sequences were edited, trimmed and assembled with the Staden package software (Staden 1996). The full-length sequences were aligned with Clustal W (Thompson et al. 1994). Sequences were deposited to GenBank (Table 1). A BLASTN search (Altschul et al. 1997) for the three loci was carried out to find homologies with other available sequences from GenBank. Considering the recent revision by Calvo \& Aedo (2015), sequences of the so-called $S$. doria specimens of western Europe were labelled as S. altissimus. MEGA ver. 7 (Tamura et al. 2013) was used to obtain Kimura two parameter (K2p - Kimura 1980) pairwise distances among the analysed sequences, expressed as average in percentage (\%).

Phylogram was inferred using the Bayesian statistics and by adopting the Markov Chain Monte Carlo (MCMC) sampling technique in the BEAUti/BEAST v.1.10.0 software (Bouckaert et al. 2014). Tamura-Nei model was setnas substitution model (Tamura and Nei 1993) and the construction of the dendrogram was computed in FigTree v. 1.4.3 (http://tree.bio.ed.ac.uk/software/figtree/). The maximum clade credibility tree was generated with nodes based on mean heights, where branches were collapsed at the $50 \%$ threshold of posterior values.

\subsection{Distribution and conservation status}

In order to outline the current distribution of $S$. fontanicola, several data were considered: herbarium specimens (see Supplementary material S1), species distribution atlas of Austria (Fisher et al. 2008) and north-eastern Italy (Poldini \& Oriolo 2002) verified with field surveys when possible, bibliography (in particular Calvo \& Aedo 2015, Vreš et al. 2012, Frattini 2008, Grulich \& Hodálová 1994), field observations, and personal communications. The conservation status was assessed following IUCN Red List Criteria version, 3.1 second edition (IUCN 2012). The criterion $B$ was selected for the assessment. The area of occupancy (AOO index) was applied to $2 \mathrm{~km}^{2}$ grid cells based on UTM grid.

\section{Results}

\subsection{Molecular analysis}

DNA were successfully extracted from all samples. DNA amplification rates differed among loci with the maximum (92\%) for the $t r n \mathrm{H}-p s b \mathrm{~A}$ locus, $69 \%$ for $r b c \mathrm{~L}$ and $85 \%$ for ITS, in agreement with literature (Kress et al. 2005, Hollingsworth et al. 2008). The total number of new sequences generated in this study was 145 . ITS locus revealed the major variability among sequences, presenting 1 indel and 26 SNPs (18 transitions and 8 transversions) for a total of 27 variable sites. The aligned sequence

Table 2: Primers and reaction conditions used for PCR.

Tabela 2: Oligonukleotidni začetniki (prajmerji) in reakcijski pogoji za verižno reakcijo s polimerazo (PCR).

\begin{tabular}{|c|c|c|c|}
\hline Locus & $\begin{array}{l}\text { Primer } \\
\text { name }\end{array}$ & $\begin{array}{l}\text { Primer } \\
\text { sequence }\end{array}$ & Reaction condition \\
\hline trnH-psbA & $\begin{array}{l}\text { psbA3'f } \\
\text { trnHf }\end{array}$ & $\begin{array}{l}\text { 5'-GTTATGCATGAACGTAATGCTC } \\
\text { 5'-CGCGCATGGTGGATTCACAATCC }\end{array}$ & $\begin{array}{l}95^{\circ} \mathrm{C} 5 \text { min } \\
94^{\circ} \mathrm{C} 30 \mathrm{~s}, 58^{\circ} \mathrm{C} 30 \mathrm{~s}, 72^{\circ} \mathrm{C} 30 \mathrm{~s}, 38 \text { cycles } \\
72^{\circ} \mathrm{C} 10 \mathrm{~min}\end{array}$ \\
\hline rbcLa & $\begin{array}{l}\text { rbcLa_f } \\
\text { rbcLa_rev }\end{array}$ & $\begin{array}{l}\text { 5'-ATGTCACCACAAACAGAGACTAAAGC } \\
\text { 5'-GTAAAATCAAGTCCACCRCG }\end{array}$ & $\begin{array}{l}95^{\circ} \mathrm{C} 5 \mathrm{~min} \\
94^{\circ} \mathrm{C} 30 \mathrm{~s}, 55^{\circ} \mathrm{C} 1 \mathrm{~min}, 72^{\circ} \mathrm{C} 1 \mathrm{~min}, 5 \text { cycles } \\
94^{\circ} \mathrm{C} 30 \mathrm{~s}, 54^{\circ} \mathrm{C} 1 \mathrm{~min}, 72^{\circ} \mathrm{C} 1 \mathrm{~min}, 30 \text { cycles } \\
72^{\circ} \mathrm{C} 10 \mathrm{~min}\end{array}$ \\
\hline ITS & $\begin{array}{l}\text { ITS4 } \\
\text { ITS5a }\end{array}$ & $\begin{array}{l}\text { 5'-TCCTCCGCTTATTGATATGC } \\
\text { 5'-CCTTATCATTTAGAGGAAGGAG }\end{array}$ & $\begin{array}{l}95^{\circ} \mathrm{C} 5 \mathrm{~min} \\
94^{\circ} \mathrm{C} 30 \mathrm{~s}, 63^{\circ} \mathrm{C} 30 \mathrm{~s}, 72^{\circ} \mathrm{C} 45 \mathrm{~s}, 8 \text { cycles } \\
94^{\circ} \mathrm{C} 30 \mathrm{~s}, 55^{\circ} \mathrm{C} 30 \mathrm{~s}, 72^{\circ} \mathrm{C} 45 \mathrm{~s}, 30 \text { cycles } \\
72^{\circ} \mathrm{C} 10 \mathrm{~min}\end{array}$ \\
\hline
\end{tabular}


length was $642 \mathrm{bp}$ including indel. For $r b c \mathrm{~L}$ and $t r n \mathrm{H}-$ $p s b \mathrm{~A}$ the aligned sequence matrix was 512 and $363 \mathrm{bp}$ in length (no indel) respectively (Table 3 ).

The total variation among sequences was attributable to inter-specific divergence. No intra-specific variability was observed for $r b c \mathrm{~L}$ and $t r n \mathrm{H}-p s b \mathrm{~A}$ loci and only one SNP was found in the ITS locus for 2 specimens of $S$. fontanicola $(\mathrm{K} 2 \mathrm{p}=0.20 \%$, Techelweg population, Austria). The range of variation extends from 0.40 to $4.21 \%$ of informative positions, with the major presence of SNPs in the nuclear ITS locus (Table 3). This locus clearly distinguished the two species analysed. Senecio doria presents 7 diagnostic positions ( 4 transitions and 3 transversions) and 1 indel, whereas $S$. fontanicola has 8 diagnostic positions (6 transitions and 2 transversions). Plastid loci were very conserved but sufficiently variable to distinguish $S$. fontanicola from $S$. doria, with 2 variable sites for $r b c \mathrm{~L}$ $(\mathrm{K} 2 \mathrm{p}=0.39 \%)$ and 3 for $t r n \mathrm{H}-\mathrm{p} s \mathrm{~A}(\mathrm{~K} 2 \mathrm{p}=0.83 \%)$.

The homology search returned 13 ITS sequences attributed to $S$. altissimus (Calvo et al. 2013). No sequences were found for the other two loci. Table 4 lists species, localities, and GenBank accession numbers. Some variability was noticed within the $S$. altissimus ITS sequences retrieved from GenBank. This variability reflected 15 variable positions $(\mathrm{K} 2 \mathrm{p}=1.27 \%)$. In any case there was no overlap with the interspecific variability.

$S$. fontanicola sequences were easily distinguished from S. altissimus $(\mathrm{K} 2 \mathrm{p}=2.28 \%)$. A graphical representation of the relationship of the considered taxa is reported in Figure 1. Three monophyletic clades clearly distin-

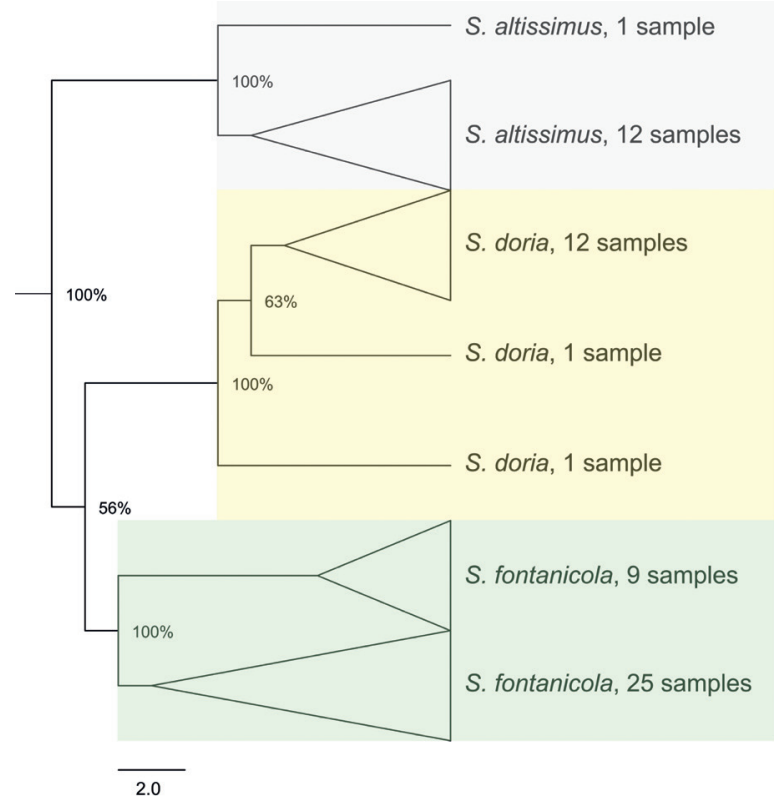

Figure 1: Cladogram obtained from FigTree software after Bayesian interference analysis computed in BEAST for the nuclear data set (ITS locus). Branches corresponding to partitions reproduced in less than $50 \%$ of posterior values were collapsed. The three clades corresponded to the three analysed species are highlighted with different colours.

Slika 1: Kladogram, rekonstruiran na osnovi jedrnega markerja (ITS) z uporabo Bayesovega principa v programu BEAST. Za prikaz smo uporabili programsko orodje FigTree. Razvejitve kladograma, ki so imele v pripadajočem kolenu nižjo podporo od 50\%, smo strnili (kolapsirali). Trije kladi, označeni z različnimi barvami, pripadajo trem vrstam, vključenim v analizo.

Table 3: Amplification rates (expressed in percentage), number of sequenced specimens, alignment length, transition/transversion rate, informative indels, total number of variable positions compare to the respective loci length and total SNP percentage of the loci ITS, $r b c L$ and $t r n H-p s b A$.

Table 3: Pomnožitvene stopnje (v odstotkih), število sekvenciranih primerkov, poravnava zaporedij, stopnja tranzicije/transverzije, informativne delecije ali duplikacije, skupno število spremenljivih pozicij v primerjavi z dolžino lokusov in skupen odstotek SNP lokusov ITS $r b c L$ in $t r n H-p s b A$.

\begin{tabular}{lccccccc} 
Locus & $\begin{array}{c}\text { Amplification } \\
\text { rates }(\%)\end{array}$ & $\begin{array}{c}\text { N. sequenced } \\
\text { specimens }\end{array}$ & $\begin{array}{c}\text { Alignment } \\
\text { length (bp) }\end{array}$ & $\begin{array}{c}\text { Transition/ } \\
\text { transversion rate }\end{array}$ & $\begin{array}{c}\text { Informative } \\
\text { indels }\end{array}$ & $\begin{array}{c}\text { N. variable } \\
\text { positions }\end{array}$ & $\begin{array}{c}\text { SNPs \% for } \\
\text { total length }\end{array}$ \\
ITS & 85 & 50 & 642 & 2,28 & 1 & $27 / 642$ & 4,21 \\
rbcL & 69 & 41 & 512 & 2,00 & 0 & $2 / 512$ & 0,40 \\
trnH-psbA & 92 & 54 & 363 & 0,33 & 0 & $3 / 363$ & 0,83 \\
\hline
\end{tabular}

Table 4: Sampling sites and GenBank accession numbers of BLASTN homology search for the ITS locus (Calvo et al. 2013). Tabela 4: Vzorčne lokacije in pristopne številke iz sekvenčne podatkovne baze (GenBank) za poizvedovanje BLAST nukleotidnukleotid homologije za ITS lokus (Calvo et al. 2013).

Senecio altissimus

Close to the Arreo lake, margin of the road (Spain) JX895272, JX895273, JX895277, JX895275, JX895276, JX895271, JX895270, JX895269, JX895268, JX895266, JX895265, JX895267 
guished the three species, i.e., S. altissimus, S. doria, and S. fontanicola. Therefore, these results also confirm the morphological distinction stated by Calvo \& Aedo (2015) between $S$. doria and S. altissimus; where a total of 3 transitions, 1 transversion and 2 informative indels unambiguously identify $S$. altissimus samples $(\mathrm{K} 2 \mathrm{p}=$ $2.20 \%)$.

\subsection{Distribution update}

Senecio fontanicola distribution is about $15580 \mathrm{~km}^{2}$, which extends throughout northern Italy, western Slovenia and southern Austria (Figure 2, Ehrendorfer and Hamman 1965).

The species shows a scattered distribution due to its ecological requirements, strictly linked to black-bog-rush fens. The major populations are located in low flats of the Friuli-Venezia Giulia Region (NE-Italy) and in the Gail valley of Carinthia Region (Austria). The species is also present in Lombardy and Veneto (N-Italy) and in the Gorenjska region (Slovenia). The Austrian populations, occurring from Bad Bleiberg up to Bleiburg (Hartl et al.
1992, Fisher et al. 2008), are the largest in terms of both surface area and number of individuals (more than 100 individuals per population). In Slovenia, only one record is reported for the alpine Zelenci wet area (Vreš et al. 2012), placed less than $5 \mathrm{~km}$ away from the easternmost Italian locality, in the Scichizza swamp (Fusine wet area, Friuli-Venezia Giulia).

Italian populations are smaller in surface area and number of individuals. In Friuli-Venezia Giulia, S. fontanicola is considered a rare taxon, occurring in several localities of lowland wetlands with populations of less than ten individuals (Pavan \& Costalonga 2001, Martini \& Pavan 2008). The species was also reported for an isolated site nearby Tolmezzo, but its presence there has not been recently confirmed. In the Veneto Region is recorded from the Onara wet area (Padua) and one isolated locality in Lombardy represents the western distribution limit of the species. This last locality is seriously threatened because of drainage activities carried out during the last decade (Frattini 2008). Some historical records e.g. Dimon and Amariana mountains in Friuli (Morassi herbarium, MFU), Euganei hills in Veneto (Ugolini herbarium, pri-

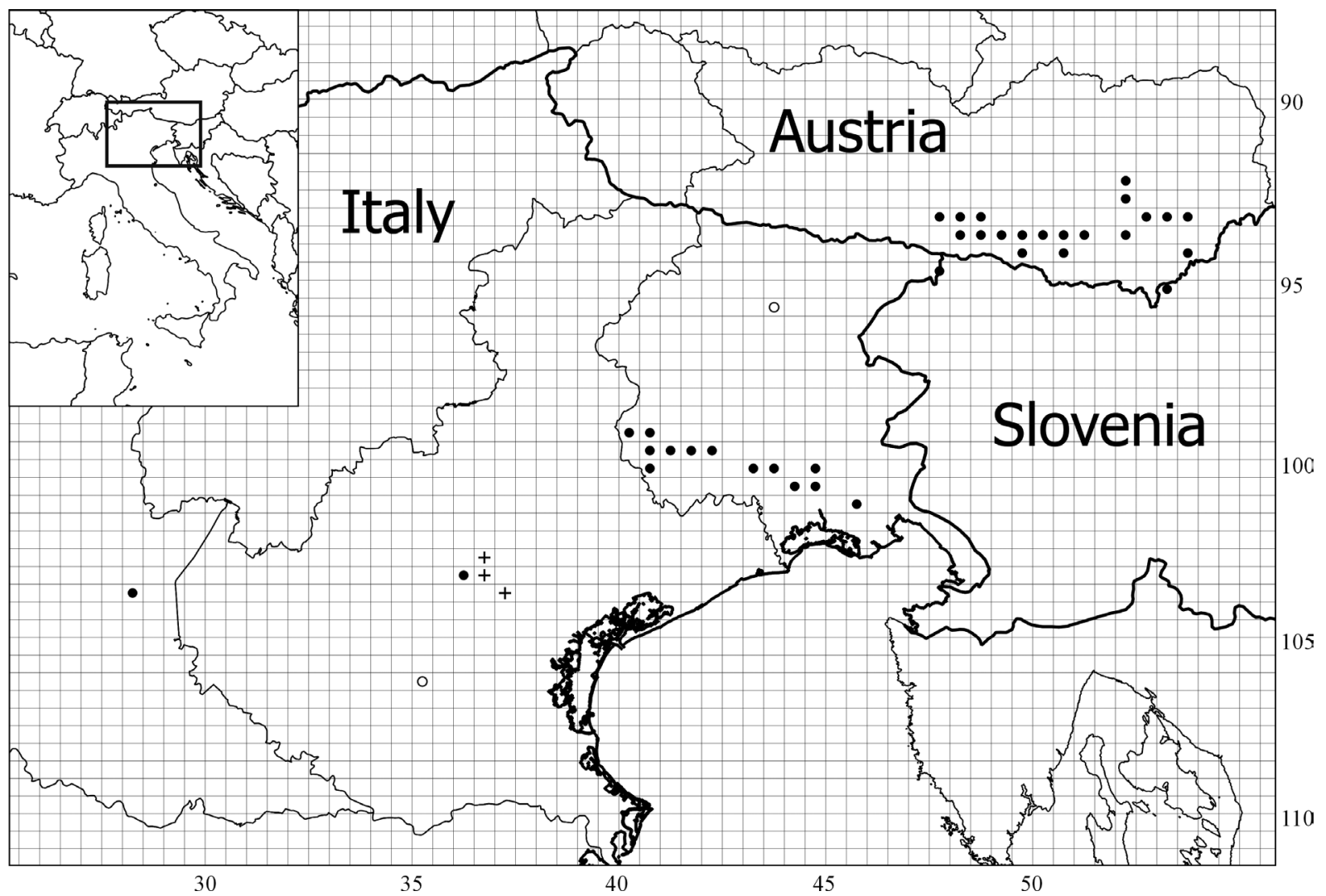

Figure 2: Distribution of Senecio fontanicola based on Ehrendorfer \& Hamman grid (1965). Legend: • present, ○ doubtful, + extinct. Slika 2: Razširjenost vrste Senecio fontanicola, prikazana na srednjeveropski mreži (Ehrendorfer \& Hamman 1965). Legenda: • sedanja, o dvomljiva, + izumrla. 
vate) are questionable because the specification of the locality is generic and the current lack of suitable ecological conditions for the species, but the existence of adequate environmental conditions in the past (at least in the Euganei hills) cannot be excluded.

\subsection{IUCN assessment}

More than $45 \%$ of sites where $S$. fontanicola falls inside protected areas (percentage obtained from the overlapping of $S$. fontanicola populations and areas subject to legal protection, online available at http://irdat.regione. fvg.it/WebGIS/ and https://www.data.gv.at/katalog/ dataset?tags=Schutzgebiet). However, the preferential habitat of S. fontanicola (7230 alkaline fens, Natura 2000) is considered "unfavourable-inadequate" for the whole continental and alpine bioregion and in particular "unfavourable-bad" for Austria and Italy (EEA 2013). Furthermore, S. fontanicola populations frequently have less than 10 plants, entailing the need of management programs for species preservation and the definition of a conservation status.

For the assessment based on IUCN Red List criteria (IUCN, 2012), the geographic criterion B was considered. The extent of occurrence (EOO) of $S$. fontanicola is $16173 \mathrm{~km}^{2}$. The calculated area of occupancy (AOO), based on the $2 \mathrm{~km}^{2}$ grid cells, is $220 \mathrm{~km}^{2}\left(108 \mathrm{~km}^{2}\right.$ in Austria, $4 \mathrm{~km}^{2}$ in Slovenia, and $108 \mathrm{~km}^{2}$ in Italy). Populations are severely fragmented and the habitat suffers reduction and degradation, mainly due to human land-use changes (Bondesan, 1995). A regression is also observed in the number of sites where the species thrives, in the size of populations, and in the extent and quality of the habitat. For these reasons, the global risk category proposed for the conservation status of $S$. fontanicola is EndangeredEN B2ab(i,ii,iii,iv).

\section{Discussion}

In this work, the molecular data supports the taxonomic treatment of $S$. fontanicola at the specific rank. Senecio fontanicola plastid sequences were very conserved and clearly separated from $S$. doria. Moreover, the molecular analysis of ITS sequences supported the recent taxonomic decision of recognizing $S$. altissimus as a species distinct from S. doria (Calvo \& Aedo 2015). This data confirmed the usefulness of ITS as a DNA barcode for the Asteraceae family (Gao et al. 2010). Sheth \& Thaker (2017) asserted that DNA barcoding not only integrates taxonomy and accomplishes species identification but also stands as a tool for species conservation, especially dealing with endemism and threatened species. In fact, the distribution of $S$. fontanicola leads us to consider this species an endemism that probably underwent allopatric speciation during the Quaternary, driven by geographical isolation from the $S$. doria. In this period, the Austrian territory was covered by ice (Ehlers \& Gibbard 2004) while the eastern zone of the North-Italian plain was covered by wet surfaces (Fontana et al. 2014), offering a putative refuge for these populations. The plant probably moved towards the Austrian wet areas, after the glaciation, following the Tagliamento and Fella rivers. This hypothesis is suggested considering the chorology and the speciation of other endemic taxa thriving in the same geographical area, such as Erucastrum palustre (Pirona) Vis. (Martini \& Poldini 1986) and Armeria helodes F. Martini \& Poldini (Martini \& Poldini 1987). Senecio fontanicola appears seriously threatened showing a scattered distribution and small populations (some of them have less than ten individuals). The IUCN attribution as Endangered species leads us to recommend the application of urgent conservation measures for the preservation of this species and its habitat.

\section{Conclusion}

The genetic characterisation and the monitoring of species distribution are the basis for the conservation of the threatened species, such as $S$. fontanicola. Molecular analysis confirmed the different taxonomic position of $S$. fontanicola from $S$. doria s.s. and the need to extend further surveys on the neighbouring $S$. altissimus. Being S. altissimus distribution neighbouring to $S$. fontanicola, it could gather interesting information about species differentiation inside the $S$. doria group, e.g. reconstructing species speciation in time using specific genetic analysis like AFLP. Moreover, the current records of S. altissimus in Italy presented in Calvo and Aedo (2015) , are highly unlikely, being based on old herbaria records. The genetic characterisation of the recently described species $S$. morisii (Sardinia - Calvo \& Aedo 2015) should also be considered in future studies.

The updated distribution of $S$. fontanicola allowed to define correctly the conservation status for the species. While a risk category was already attributed to the Austrian populations (EN), any active measures for species conservation are being applied in Italy and Slovenia. The definition of the Endangered (EN) risk category points out the critical status of the species, highlighting the need of urgent and effective measures at both European and national level. 


\section{Acknowledgments}

Authors would like to thank I. Hodálová (Institute of Botany, Bratislava, Slovak Republic) for the plant material kindly sent to us and W. Franz for helping in the field surveys through Austria. Moreover, we thank G. Bertani, S. Costalonga, G. Mainardis, R. Masin, P. Merluzzi, R. Pavan, and E. Zanotti for sharing the data on the species distribution in Italy, B. Vreš (Institute of Biology, Scientific Research Centre of the Slovenian Academy of Sciences and Arts) for clarifying some records from Slovenia and L. Strazzaboschi for elucidating the procedure of defining the risk category using IUCN criteria. We are also grateful to the Directors and Curators of the herbaria mentioned in the text. Eventually, we are grateful to G. Bacchetta (University of Cagliari, Sardinia) for the critical discussion of the work.

Elisa Pellegrini (D), https://orcid.org/0000-0002-6972-9540

Valentino Casolo (D, https://orcid.org/0000-0003-4398-5519

Duilio lamonico (D), https://orcid.org/0000-0001-5491-7568

Massimo Vischi(D), https://orcid.org/0000-0002-6632-7749

\section{References}

Altschul, S. F., Madden, T. L., Schaffer, A. A., Zhang, J., Zhang, Z., Miller, W. \& Lipman, D. J. 1997: Gapped BLAST and PSI-BLAST: a new generation of protein database search programs. Nucleic Acids Research 25: 3389-3402.

Bartolucci, F., Peruzzi, L., Galasso, G., Albano, A., Alessandrini, A., Ardenghi, N. M. G., Astuti, G., Bacchetta, G., Ballelli, S., Banfi, E., Barberis, G., Bernardo, L., Bouvet, D., Bovio, M., Cecchi, L., Di Pietro, R., Domina, G., Fascetti, S., Fenu, G., Festi, F., Foggi, B., Gallo, L., Gottschlich, G., Gubellini, L., Iamonico, D., Iberite, M., Jiménez-Mejías, P., Lattanzi, E., Marchetti, D., Martinetto, E., Masin, R. R., Medagli, P., Passalacqua, N. G., Peccenini, S., Pennesi, R., Pierini, B., Poldini, L., Prosser, F., Raimondo, F. M., Roma-Marzio, F., Rosati, L., Santangelo, A., Scoppola, A., Scortegagna, S., Selvaggi, A., Selvi, F., Soldano, A., Stinca, A., Wagensommer, R. P., Wilhalm, T. \& Conti, F. 2018: An updated checklist of the vascular flora native to Italy. Plant Biosystems 152(2): 179-303.

Bondesanf, M., Castiglioni, G. B., Elmis, C., Gabbianellis, G., Marocco, R., Pirazzolift, P. A. \& Tomasin, A. 1995: Coastal areas at risk from storm surges and sea-level rise in northeastern Italy. Journal of Coastal Research 11(4): 1354-1379.

Bouckaert, R., Heled, J., Kühnert, D., Vaughan, T., Wu, C-H., Xie, D., Suchard, MA., Rambaut, A., \& Drummond, A. J. 2014: BEAST 2: A Software Platform for Bayesian Evolutionary Analysis. PLoS Computational Biology 10(4): e1003537.

Calvo, J. \& Aedo, C. 2015: A Taxonomic Revision of the Eurasian / Northwestern African Senecio doria Group (Compositae). Systematic Botany 40(3): 900-913.

Calvo, J., Álvarez, I., Aedo, C. \& Pelser, P. B. 2013: A phylogenetic analysis and new delimitation of Senecio sect. Crociseris (Compositae:
Senecioneae), with evidence of intergeneric hybridization. Taxon 62(1): 127-140.

Calvo, J., Vitek, E. \& Aedo, C. 2014: (2295) Proposal to conserve the name Senecio doria (Compositae) with a conserved type. Taxon 63(3): 685-686.

CBOL Plant Working Group. 2009: A DNA barcode for land plants. PNAS, 106: 295-299.

Conti, F., Abbate, G., Alessandrini, A. \& Blasi, C. 2005: An annotated Check-list of the Italian Vascular Flora. Roma: Palombi Editori, 428 pp.

Conti, F., Manzi, A. \& Pedrotti, E. 1992: Il libro rosso delle piante d'Italia. W.W.F. and S.B.I. Camerino, 637 pp.

Conti, F., Manzi, A. \& Pedrotti, E. 1997: Liste rosse regionali delle piante d'Italia. Dep.. of Botany and Ecology. University of Camerino, $139 \mathrm{pp}$.

Doyle, J. J. \& Doyle, J. L. 1997: A rapid DNA isolation procedure for small quantities of fresh leaf tissue. Phytochemistry Bulletin 19: $11-15$.

EEA, 2013: Available data for mapping and assessing ecosystems in Europe. Final Report-task 5.2.5_3_Ecosystem assessment: Identification of thematic datasets. Available: http://projects.eionet.europa.eu/ eea-ecosystem-assessments/library/workingdocument-data-availability/ ecosystem-assessment-data-availability_report_03-june-2013

Ehlers, J. \& Gibbard, P. L. 2004: Quaternary Glaciations: Extent and Chronology Part I: Europe. Elsevier: London, 388 pp.

Ehrendorfer, F. \& Hamman, U. 1965: Vorschläge zu einer floristischen Kartierung von Mitteleuropa. Berichte der Deutschen Botanischen Gesellschaft 78: 35-50.

Ewing, B. \& Green, P. 1998: Basecalling of automated sequencer traces using Phred. II. Error probabilities. Genome Research 8: 186-194.

Fisher, M. A., Oswald, K. \& Adler, W. 2008: Exkursionsflora für Österreich, Liechtenstein, und Südtirol. 3. Aufl.- Linz: Land Oberösterreich, Biologiezentrum der Oberösterr. Landesmuseen, 934 pp.

Fontana, A., Mozzi, P. \& Marchetti, M. 2014: Alluvial fans and megafans along the southern side of the Alps. Sedimentary Geology 301: 150-171.

Frattini, S. 2008: Zone umide della pianura bresciana e degli anfiteatri morenici dei Laghi d'Iseo e di Garda (provincia di Brescia, regione Lombardia). Natura Bresciana 29: 93-95.

Gao, T., Yao, H., Song, J. Y., Liu, C., Zhu, Y. J., Ma, X. Y., Pang, X. H., Xu, H. X. \& Chen, S. L. 2010: Identification of medicinal plants in the family Fabaceae using a potential DNA barcode ITS2. Journal of Ethnopharmacology 130: 116-121.

Grulich, V. \& Hodálová, I. 1994: The Senecio doria Group (AsteraceaeSenecionae) in Central and Southeastern Europe. Phyton (Horn) Austria 34: 247-265.

Hartl, H., Kniely, G., Leute, G. H., Niklfeld, H. \& Perko, M. 1992: Verbreitungsatlas der Farn- und Blütenpflanzen Kärntens. Klagenfurt, $325 \mathrm{pp}$.

Hollingsworth, P. M. 2008: DNA Barcoding plants in biodiversity hotspots: progress and outstanding questions. Heredity 101: 1-2.

Hollingsworth, M. L., Clark, A. A., Forrester, L. L., Richardson, J., Pennington, R. T., Long, D. G., Cowan, R., Chase, M. W., 
Gaudeul, M. \& Hollingsworth, P. M. 2009: DNA Barcoding. Selecting Barcoding loci for plants: evaluation of seven candidate loci with species-level sampling in three divergent groups of land plants. Molecular Ecology Resources 9: 439-457.

Hollingsworth, P. M., Li, D. Z., van der Bank, M. \& Twyford, A. D. 2016: Telling plant species apart with DNA: from barcodes to genomes. Philosophical Transactions of the Royal Society B. 371(1702): 20150338.

Iamonico, D. 2013: Lectotypification of Senecio doria (Asteraceae). Annales Botanici Fennici 50(1-2): 71-72.

Iamonico, D. 2017: Alien taxa of the tribe Senecioneae (Asteraceae) in Italy: a nomenclatural synopsis. Hacquetia 16(2): 281-292.

IUCN. 2012: IUCN Red List Categories and Criteria: Version 3.1. Second edition. Gland, Switzerland and Cambridge, UK: IUCN. iv + 32 pp.

Kang, Y., Deng, Z., Zang, R. \& Long, W. 2017: DNA barcoding analysis and phylogenetic relationships of tree species in tropical cloud forests. Scientific reports 7(1):12564.

Khan, S., Al-Qurainy, F., Nadeem, M. \& Tarroum, M. 2013: Selection of chloroplast DNA markers for the development of DNA barcode and reconstruction of phylogeny of Senecio asirensis boulos and jri wood. Pakistan Journal of Botany 45(2): 703-710.

Kimura, M. 1980: A simple method for estimating evolutionary rate of base substitutions through comparative studies of nucleotide sequences. Journal of Molecular Evolution 16: 111-120.

Kress, W. J., Wurdack, K. J., Zimmer, E. A., Weigt, L. A. \& Janzen, D. H. 2005: Use of DNA barcodes to identify flowering plants. Proceedings of the National Academy of Science U.S.A. 102: 8369-8374.

Martini, F. \& Poldini, L. 1986: Distribution and ecology of Erucastrum palustre (Pir.) Vis. Gortania, Atti Museo Friulano di Storia Naturale 8: 221-224.

Martini, F. \& Poldini, L. 1987: Armeria helodes, a new species from North-Eastern Italy. Candollea 42(2): 533-544.

Martini, F. \& Pavan, R. 2008: La flora vascolare spontanea di Pordenone: caratteri generali e distribuzione. Pordenone: Museo civico di storia natural, $277 \mathrm{pp}$.

Milton, J. J. 2009: Phylogenetic analyses and taxonomic studies of Senecioninae: Southern african Senecio section Senecio [thesis]. Saint Andrews: University of St Andrews, Scotland.

Niklfeld, H. \& Schratt-Ehrendorfer, L. 1999: Rote Liste gefährdeter Farn- und Blütenpflanzen (Pteridophyta und Spermatophyta) Österreichs. 2. Fassung. In: Niklfeld, H. (eds.): Rote Listen gefährdeter Pflanzen Österreichs. Grüne Reihe des Bundesministeriums für Umwelt, Jugend und Familie 353-392.

Nordenstam, B. 2007: Tribe Senecioneae In: Kadereit, J.W. \& Jeffrey, C. (eds.): Flowering Plants. Eudictos. Asterales. Vol. 8 of Kubitzki, J. (eds.): The Families and Genera of Vascular Plants. Springer, Berlin, Germany 208-241.

Pavan, R. \& Costalonga, S. 2001: Flora delle zone umide dell'alto Livenza. Sacile: Associazione Naturalisti Sacile, 127 pp.

Pelser, P. B., Nordenstam, B., Kadereit, J. W. \& Watson, L. E. 2007: An ITS phylogeny of Tribe Senecioneae (Asteraceae) and a new delimitation of Senecio L. Taxon 56: 1077-1104.
Pelser, P. B., Kennedy, A. H., Tepe, E. J., Shidler, J. B., Nordenstam, B., Kadereit, J. W. \& Watson, L. E. 2010: Patterns and causes of incongruence between plastid and nuclear Senecioneae (Asteraceae) phylogenies. American Journal of Botany 97: 856-873.

Peruzzi, L., Bedini, G. \& Andreucci, A. 2012: Homoploid hybrid speciation in Doronicum L. (Asteraceae)? Morphological, karyological and molecular evidences. Plant Biosystems 146(4): 867-877.

Pignatti, S., Menegoni, P. \& Giacanelli, V. 2001: Liste rosse e blu della flora italiana. ANPA, $328 \mathrm{pp}$.

Pirona, J. A. 1855: Florae forojuliensis syllabus. Udine: Tip. Vendrame, $170 \mathrm{pp}$.

Poldini, L., Oriolo, G. \& Vidali, M. 2001: Vascular Flora of FriuliVenezia Giulia. An Annotated Catalogue and Synonimic Index. Studia Geobotanica 21: 3-227.

Poldini, L. \& Oriolo, G. 2002: Alcune entità nuove e neglette per la flora italiana. Informatore Botanico Italiano 34: 105-114.

Rossi, G., Montagnani, C., Gargano, D., Peruzzi, L., Abeli, T., Ravera, S., Cogoni, A., Fenu, G., Magrini, S., Gennai, M., Foggi, B. Wagensommer, R. P., Venturella, G., Blasi, C., Raimondo, F. M. \& Orsenigo, S. 2013: Lista Rossa della Flora Italiana 1. Policy Species e altre specie minacciate. Comitato Italiano IUCN e Ministero dell'Ambiente e della Tutela del Territorio e del Mare, 58 pp.

Sang, T., Crawford, D. J. \& Stuessy, T. F. 1997: Chloroplast DNA phylogeny, reticulate evolution, and biogeography of Paeonia (Paeoniaceae). American Journal of Botany 84: 1120-1136.

Scoppola, A. \& Spampinato, G. 2005: Atlante delle specie a rischio di estinzione. CD-ROM In: Scoppola A, Blasi C. (eds.): Stato delle conoscenze sulla Flora vascolare Italiana. Roma: Palombi Editori, $253 \mathrm{pp}$.

Sheth, B. P.\& Thaker, V. S. 2017: DNA barcoding and traditional taxonomy: an integrated approach for biodiversity conservation. Genome 60(7): 618-628.

Staden, R. 1996: The Staden Sequence Analysis Package. Molecular Biotechnology 5: 233-241.

Stanford, A. M., Hardenm R. \& Parks, C. R. 2000: Phylogeny and biogeography of Juglans (Juglandaceae) based on matK and ITS sequence data. American Journal of Botany 87: 872-882.

Tamura, K. \& Nei, M. 1993: Estimation of the number of nucleotide substitutions in the control region of mitochondrial DNA in humans and chimpanzees. Molecular Biology and Evolution 10(3): 512-526.

Tamura, K., Stecher, G., Peterson, D., Filipski, A. \& Kumar, S. 2013: MEGA6: Molecular Evolutionary Genetics Analysis version 6.0. Molecular Biology and Evolution 30: 2725-2729.

Thompson, J. D., Higgins, D. G. \& Gibson, T. J. 1994: CLUSTAL W: improving the sensitivity of progressive multiple sequence alignment through sequence weighting, position-specific gap penalties and weight matrix choice. Nucleic Acids Research 22: 4673-4680.

Vreš, B., Seliškar, A. \& Dakskobler, I. 2012: The phytosociological position of Senecio fontanicola Grulich \& Hodálová, a rare and endangered species endemic to the Eastern Alps, in the successional sere on the montane wetland Zelenci (NW Slovenia). Wulfenia 19: 1-14.

Zenari, S. 1947: Intorno ad un Senecio delle Risorgive friulane. Istituto Botanico dell'Università di Padova, Lavori di Botanica. Pinerolo: G. Alzan, 1-5. 